\title{
DETERMINATION OF PERSONALITY TRAITS AND CHARACTER OF LEADERS, THEIR SELECTION AND EFFICIENCY IN THE TEXTILE INDUSTRY
}

\author{
UDC: 005.96 \\ 005.32 \\ Original Scientific Paper \\ Jesa KREINER ${ }^{1}$, Dragana SAJFERT ${ }^{2}$, Edit TEREK ${ }^{3}$, Nikola PETROVIĆ ${ }^{2}$ \\ ${ }^{1}$ California State University, Fullerton, Los Angeles, California, USA \\ E-mail: jesakreiner@ sbcglobal.net \\ ${ }^{2}$ College Dositej, 11000 Belgrade, Bulevar vojvode Pitnika 7, Republic of Serbia \\ ${ }^{3}$ University of Novi Sad, Technical faculty „Mihajlo Pupin“, Zrenjanin, 23000 Zrenjanin, Đure Đakovića bb, \\ Republic of Serbia
}

Paper received: 08.11.2018.; Paper accepted: 17.12.2018.

\begin{abstract}
The approach to management as a set of specificity means is that organizations will work better if people in leadership positions have certain traits. Practical but essential task of leaders is to create new approaches and find new areas to explore. The hypothesis underlying this procedure is that the personality traits of leaders have a major impact on increasing their effectiveness and efficiency in the textile industry in Serbia. In the study, the results were given for the age structure, professional structure of the leaders, social origin of the leader, the leader position in society, the success of the work of managers, the importance of some roles of managers. Knowledge and skills are acquired and developed through theory and practical experience, while some specific skills are a starting feature that an individual has or does not have. A leader is a profession that requires a person to possess certain character traits to be successful, in order to successfully carry out the tasks.
\end{abstract}

Keywords: Personality traits, Selection, Efficiency, Leader, Manufacturing.

\section{INTRODUCTION}

Traits are relatively stable characteristics, such as abilities, psychological motives, or consistent patterns of behaviour.Personality traits can be defined as individual's characteristic patterns of thought, emotion and behaviour that gives consistency and individuality to a person (Feist \& Feist, 2009). According to the trait theory of personality, leaders are taller, have more confidence and are physically more durable (i.e. have more energy) than non-leaders. Gladwell states that in the U.S. population only about 14.5 percent of all men are 182 centimetres or over, among CEOs of Fortune 500 companies, 58 percent are 182 centimetres or taller, according to Kaul (2011). For some time it was considered that the trait theory of personality was wrong and that there were no consistent differences in personality traits between leaders and those who were not, or between successful and unsuccessful
leaders.Research results recently obtained by some authors (House, \& Aditya, 1997; Judge, Illies, Bono, \& Gerhardt, 2002; Kirkpatrick \& Locke, 1991) suggest that "successful leaders are not like other people", and that they actually do differ from those who are not leaders.

The hypothesis underlying the procedures of leaders' traits is that the professional selection of the right people will increase the efficiency of their functions, and thus their impact on the production process in Serbia. Organizations dealing with the production process can specify the characteristics or qualities that are important to them in certain positions and then take advantage of techniques for assessing personality in order to determine whether a person meets their needs.In that way the dominant traits or characteristics that a leader shows are found, as well as the characteristics of those individuals who possess such qualities are searched for.The task of the organization is to, by 
using a variety of primarily psychological techniques for assessing personality, find these people and place them in suitable jobs.

For some time, analysing the characteristics of the leaders was not interesting, but with the advent of transformational and transactional leadership that approach has been re-actualized. In recent years, except for the study of personality characteristics, the skills and capabilities have been in focus, both of which are often equated in the literature. General belief that exists in business circles around the world, according to some sources, is that leadership is the key to the efficiency of a company.

According to Krech, Crutchfield and Livson (1958), one of the most prominent aspects of group behaviour is reflected in the fact that some people become leaders while others remain followers. According to them, the main psychological problems of management are related to the leaders' functions, the ways to become a leader, the personality traits that are associated with the "ability" to manage, and to the influence of management on group functioning. Krech, Crutchfield and Livson (1958) suggests that leaders play many roles within an organization simultaneously. They may take the function of Executive, Planner, Policy maker, Expert, External group representative, Controller of internal relationships, Purveyor of rewards and punishment, Arbitrator and mediator, Exemplar, Father figure andScapegoat. These authors wonder if some people are "born leaders" or anyone can be a leader if the circumstances are favourable.

Yukl (1959) gave a definition of leadership that was accepted by many experts dealing with this topic: "the process whereby one individual influences other group members toward the attainment of defined group or organizational goals". According to Greenberg and Baron (1995) "the thing is that the leadership relies, at least partly, on a positive attitude and feelings between leaders and followers". Cialdini (1988) argues that followers accept the influence of a leader because they respect him, love him and admire him - but not because he is in a position from which derives the official authority.It can be concluded that leaders are focused on the change of those actions or attitudes of subordinates related to a specific goal, but have no intention of changing activities or attitudes related to these goals.Leaders certainly influence subordinates in different ways, but they are susceptible to the influence of their followers as well.It can be said that leadership exists only where there are followers. It is clear that without followers there are no leaders. According to Kotter (1990), the primary task of a leader is to create the basic mission of the organization and the strategy for its implementation. On the other hand, the role of a manager is to achieve this vision in practice. Manager is a means for achieving a goal or a vision created by a leader.

Bennis and Nanus (1985) argue that managers are often required to be the leaders of their subordinates and at the same time to realize the mission of a leader.It may be noted that a large number of quasi leaders are overwhelmed with managerial aspects of work that needs to be done which creates organizations where management is exaggerated and leadership suppressed.

\section{LEADERS PERSONALITY TRAITS AND CHARACTER}

Some authors (Bass, 1990; Greier, 1967) believe that effective leadership is mainly derived from personality traits of leaders or from the way they behave in public. Yukl (1959) argues that decades of active research (most conducted before 1950) did not provide a short, accurate list of common key features of leaders.Previous researches also showed some consistent findings (e.g., leaders are generally taller and more intelligent than the followers).Bass (1990), claims that, by their nature and extent, they did not significantly contribute to new knowledge. The overall results of examining traits related to leaders were a real disappointment, which led to the fact that most of the researchers gave up and concluded that leaders simply did not differ from the followers in a clear and logical way.Today, it is a topic being discussed again (and motivation for carrying out this project) because of the increasing number of evidences that suggest that the leaders are really different from the others in several important - measurable - ways. Kirkpatrick and Locke (1991) have been studying a large number of studies on this issue and came to the conclusion that the traits were an important factor - certain traits in combination with other factors contribute to the success of leaders in the business environment. According to Lord, De Vader and Alliger (1986) effective leaders should be intelligent and able to summarize and interpret the large amount of information.However, these 
authors believe that mental ingenuity is not necessary, and in some circumstances it may prove harmful.They also claim that the flexibility trait (the leaders' ability to observe the measures to be taken in a given situation and cope with changes in circumstances) is very important. According to research by Zaccaro, Foti and Kenny (1991) there are findings from which it can be concluded that the leaders are not inclined to behave the same way all the time, but can be easily adapted and can easily adjust their style to the needs of the followers or demands they are facing with. Kirkpatrick and Locke (1991) argue that regardless of being born or built, it is obvious that the leaders are not like other people. Leaders do not have to be known for their ingenuity or to be omniscient prophets to succeed, but they definitely have to posses the "real thing", and it is not equally present in each of us.Further, the authors suggest that leadership is demanding, relentless job which is followed by enormous pressures and grave responsibilities. We would do a great injustice if we were to say that leaders are ordinary people who have just found themselves in the right time at the right place. As a complement to the idea that certain traits make the difference between an effective and ineffective leader, is the principle that leaders emerge as leaders because of the way they behave and act.

There are many papers that deal with leadrs personality traits. The authors Oludele Mayowa, Faremi and Ekundayo (2016) found out that there is a relationship between leadership communication style, personality trait and organizational productivity. The subject of the paper (Wambui, Loice, \& Kimeli, 2017) is leader personality traits on employee job satisfaction. The conclusion of the aforementioned paper is that leaders who are extraverted, open to new experiences, emotionaly stable, conscientious and agreeable enhance employee job satisfaction. The results of a study (Elkington, \& Breen,2015) concluded the factors that encourage the development of leadership traits and individual and collective consciousness of leaders.

The general hypothesis of this study (GH) 1: (What) Attitudes and behaviours of leaders and determination of their personality traits have an impact on their selection, and thus on the effectiveness of the selected in the textile industry in Serbia. (Argument) The more leaders show greater understanding and differentiating of the management dimensions on its importance to the management of the textile industry in Serbia, the higher is the overall operating efficiency of the company (Function). The general hypothesis will be confirmed or refuted according to the sample of surveyed leaders in the textile industry in Serbia, and on the basis of their different dimensions, the factors of influence of a leader's personality traits will be identified, as well as the importance of individual measures of a manager's success.Auxiliary hypothesis $(\mathrm{AH})$ 1: The greater impact of personality traits of leaders, the greater the importance of certain roles of managers (Argument), and the greater the efficiency of business operations (Function).

\section{METHOD}

This survey was conducted in order to investigate the need for managers has brought some interesting information about the personality traits of a leader in the textile industry in Serbia, as well as their attitudes. Based on a sample of 110 surveyed leaders of the textile industry in the Republic of Serbia, meritorious conclusions can be presented. Descriptive analysis was used to describe the results of the questions that were asked.

\section{RESULTS AND DISCUSSION}

The age structure of the leaders of the observed companies in the textile industry is such that older people prevail. The average age of leaders is 46.3 years, while the mode, or most frequent age is 46 years. If the age range is divided into intervals of 10 years, then we can say that only $9 \%$ of leaders are in the age group between 25 and 35 years, 35\% of leaders are between 35 and 45 years, $43 \%$ of leaders are in the group 45-55 years, and $13 \%$ of leaders are over 55 years. If we bear in mind the significant need for change and adoption of new knowledge and habits, which entails the transition of our economy, it can be concluded that the age structure of the leaders in the textile industry in Serbia is not particularly favourable.

Educational level of surveyed leaders is very favourable (Figure 1.). By far the largest share in the structure of qualifications $(62 \%)$ are the leaders with university degree. It can be seen that over $80 \%$ of leaders have a university degree or specialization, master or $\mathrm{PhD}$ degree. One-fifth of the leaders have a master degree or $\mathrm{PhD}$. This is certainly good information if it is assumed that the 
leaders actually acquired the knowledge necessary to perform the work in the textile industry.

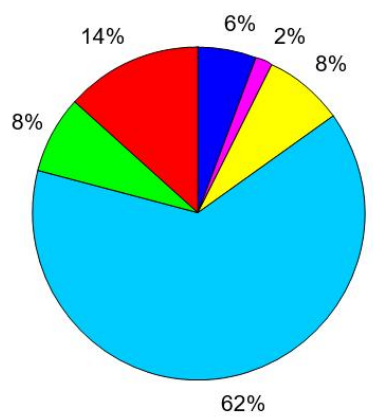

- Secondary education $\square$ College education $\square$ University degree $\square$ Specialization $\square$ Master degree $\square \mathrm{PhD}$ degree

Figure 1: The educational structure of the leaders

Structure of the leaders according to their professional profile is presented in the Figure 2.

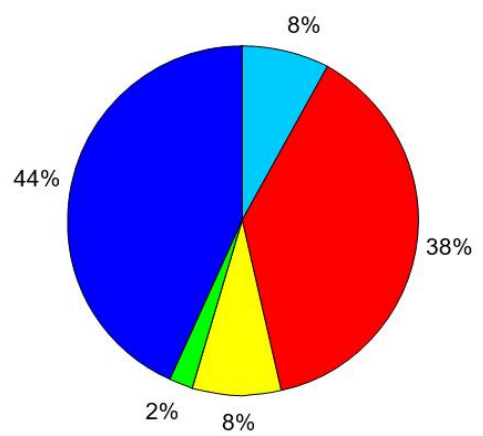

$\square$ Lawyers

$\square$ Economists $\square$ Organizers

$\square$ Remaining

- Engineers

Figure 2: Structure of the leaders according to their professional profile.

Social background of the surveyed leaders can be seen in the Figure 3.

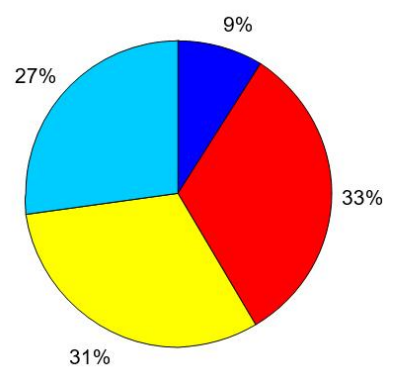

- Rural background

$\square$ Working class background

$\square$ Clerical background

$\square$ Intellectual background

Figure 3: Structure of the leaders according to their social background

The largest portion of respondents belongs to the field of economy or technical sciences - a total of $82 \%$. Individually, most of the leaders are engineers (44\%) and economists (38\%). The fact that the leaders with an engineering education prevail, implies that our leaders are generally well equipped with knowledge in the field of technology which is of particular importance to the companies in Serbian textile industry, but that they lack knowledge in some important areas of business operations such as marketing, finance, economics and the like.

By their social background leaders generally do not differ from other managers: worker-class rural background prevails over clerical background.There is a strong correlation between age and background such that younger leaders mostly come from clerical background while older have worker-class - rural background.This suggests that the social background of leaders is changing in the direction of increasing the representation of the higher social classes.

Leaders' attitudes about the professionalization of managerial work are very positive. Of the total number of surveyed leaders, $78 \%$ consider that the manager is a profession, not a function. Only $19 \%$ of them think the opposite. These attitudes of the leaders are certainly a significant step towards the professionalization of management activities in Serbia.

This is confirmed by the leaders' attitudes about the need for market, associations and trade unions for managers. Hence, $92 \%$ of surveyed leaders think that there should be the market for managers, $82 \%$ consider that the associations for managers should exist, while two-thirds of them $(66 \%)$ think that there should be the managers trade unions. The existence of market, associations and trade unions for manager would be a sure sign of professionalization of management.

The surveyed leaders are not satisfied with the existing regulations stipulating the status, rights and obligations of the leaders. This can be seen in the Figure 4.

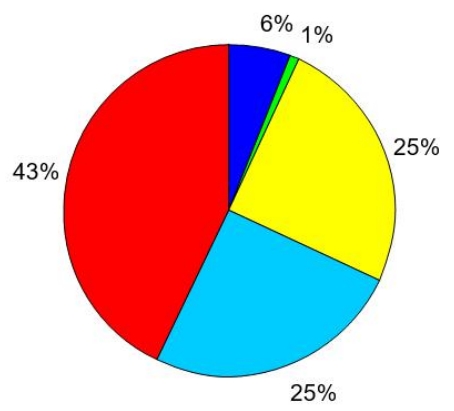

- Very favourable $\square$ Favourable $\square$ Neutral $\square$ Unfavourable - Very unfavourable

Figure 4: The position of leaders in society (leaders' evaluation)

Certainly, it is not good that half of the leaders believe that with the current legislation the position 
of manager is regulated unfavourable or very unfavourable. Only one quarter of the leaders is satisfied with the legal regulations of their position.

Leaders' evaluation of the importance of certain measures of managers'success can be seen in the Figure 5.

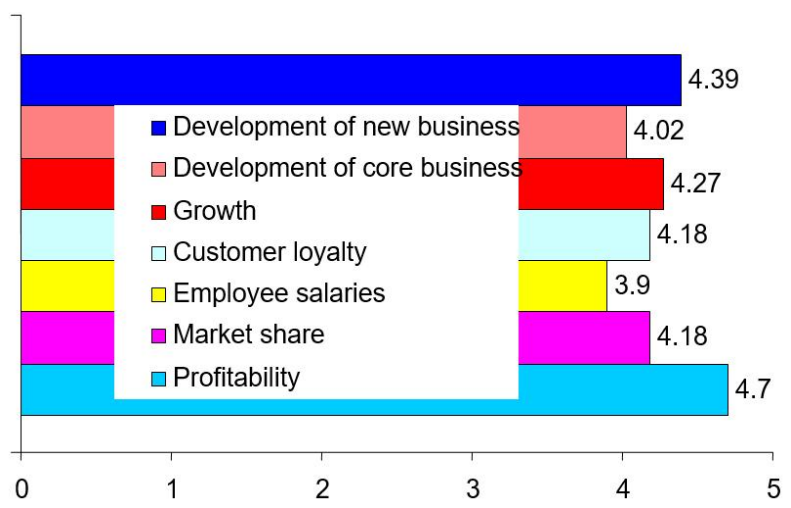

Figure 5: The importance of certain measures of managers' success (leaders' evaluation)

Note: Grades are given on a scale of 1 to $5 ; 1$ least important, 5 - most important

As can be seen, besides the profitability, leaders most value the growth of the companies in the textile industry in Serbia,through diversification into new business.

General leaders' attitude towards change is very positive. Almost all of leaders (95\%) think that changes have positive impact on companies in Serbian textile industry.In terms of the way in which changes should be performed, leaders have almost unified attitude that changes need to be made in an evolutionary manner rather than in revolutionary or "earthquake" manner. When it comes to the methods of change, leaders prefer organizational structure changes (average grade 3.88 ), then the changes by giving commands (3.56), while the least preferred method is indoctrination, persuasion and learning (3.23). World experiences in terms of methods of change are quite different, and emphasize the importance of the personalized methods rather than those depersonalized such is the change of the organizational structure.

Surveyed leaders have a very positive attitude towards consultants both internal and external ones. Three-quarters of the leaders consider internal consultants necessary, while in terms of external consultants there is a completely unified attitude on their usefulness - $95 \%$ of participants find them necessary.

According to our research, the leaders gave the highest rate to the direct supervision as a control method (average rating - 4:01). Right behind it on the scale is the prescribing mode (3.65) and planning results (3.64), while the last place takes imposing rules of behaviour (3.28). It can be concluded that in the control process the leaders prefer direct over the indirect method. Leaders' attitude towards the importance of certain roles of managers can be seen in Figure 6.

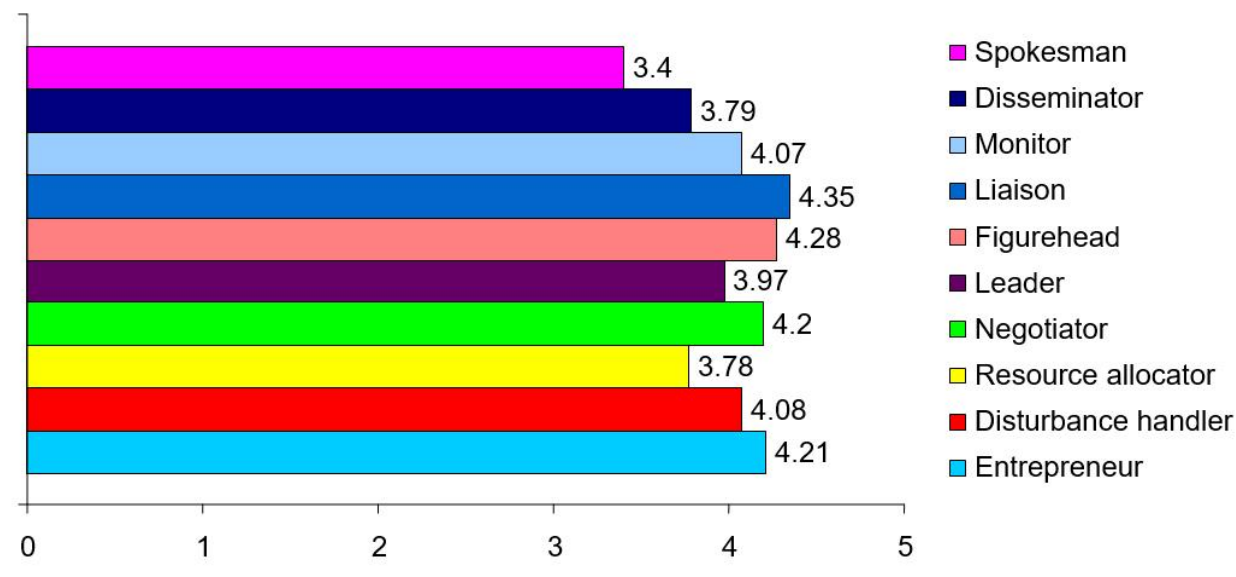

Figure 6: The importance of certain roles of managers (leaders' evaluation)

Note: Grades are given on a scale of 1 to 5; 1 - least important, 5 - most important

It is indicative that Liaison is the best ranked role of manager followed by the Figurehead role, while in the fourth place is the Negotiator role. This indicates that, according to leaders' opinion, the most important task of a Serbian textile industry manger is to establish relationships between a company and its environment that will help the company to achieve good results. Since this attitude 
is probably a product of practice in which the leaders work, it can be concluded that for the success of Serbian textile industry companies, establishing good relationships is more important than market success. Putting the Entrepreneur role in the third place can be considered a bad sign because the leaders, by definition, should play that role in their companies in Serbian textile industry.
In order to determine the differences between leaders and other managers, the analysis of variance (ANOVA) for all the questions in the questionnaire was used.The list of questions on which the leaders have different attitude compared to other managers was thus obtained.That difference is statistically significant or systematic.Differentiation of the leaders from other managers can be seen in the Figure 7.

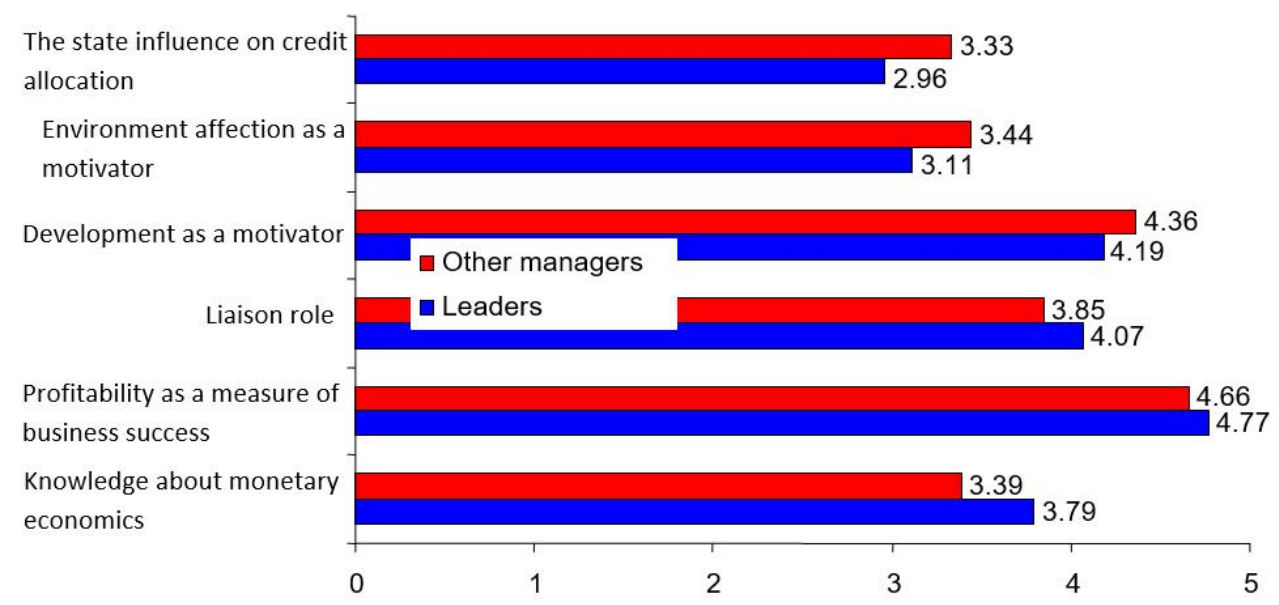

Figure 7:Differences between leaders and other managers

Grades are given on a scale of 1 to 5; 1 - least important, 5 - most important

As can be seen, the leaders have significantly higher appreciation to the knowledge of banking and monetary economics comparing to the other managers. They also more appreciate profitability, as a measure of the success of managers. Finally, leaders, more than others, rate the role of managers as the liaison. Given the leading position in the company and taking into account what is expected of them, these differences are quite logical.

Most differences between leaders and other managers exist in ranking the importance of certain stakeholders that a Serbian textile industry enterprise has to satisfy. The differences can be seen in the Figure 8.

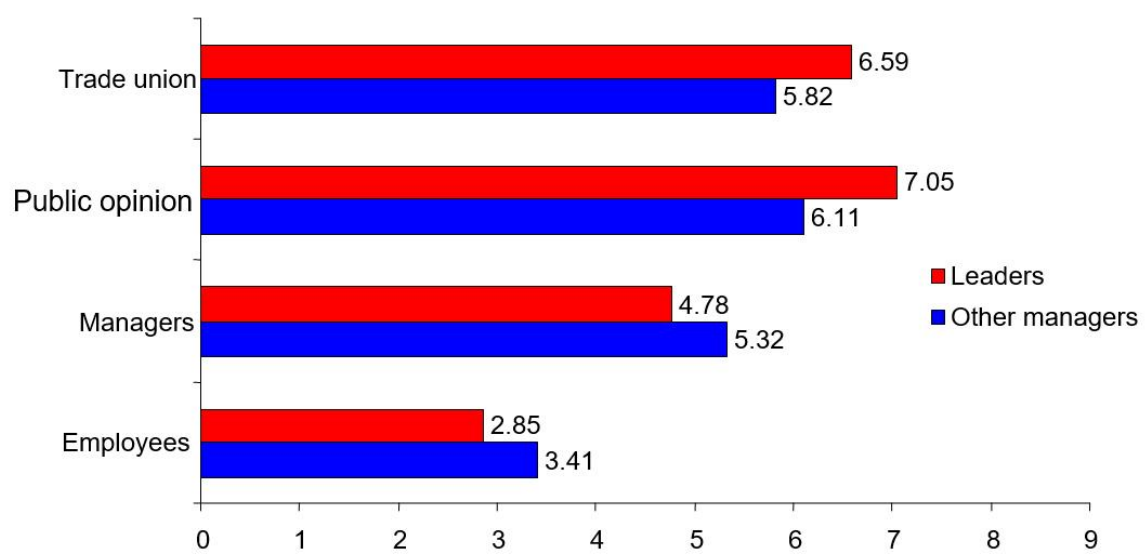

Figure 8: Differences between leaders and other managers

Grades are given on a scale of 1 to 9; 1 - the least important stakeholder, 9-the most important stakeholder

As it can be seen, the leaders,less than the others,rate the importance of employees and management as the stakeholders that the enterprise in the textile industry should satisfy through its 
operations. However, the leaders more than other managers, take care of the interests of the public opinion and the trade unions. Since the leaders are those who are considered responsible for the operation of the company by the public and trade unions, these differences of opinion are understandable.

Interestingly, leaders, less than other managers, value the state influence in the field of credit allocation. This may indicate their greater tendency towards a market economy. Also, there are significant differences in the motivation of leaders and other managers. For example, leaders are less motivated by the possibility of development and training, as well as by the affection of the environment.

Leaders are distinguished from others by their attitude towards the need to determine the maximum salary range.They significantly less than the managers find it necessary to establish the maximum salary range. $30 \%$ of leaders and $40 \%$ of other managers opted to establish this range. Also, there are differences in attitudes towards change. Leaders are more inclined towards making changes comparing to other managers: $94 \%$ leaders versus $84 \%$ of other directors considered change as a positive or very positive. Finally, $66 \%$ of leaders versus $47 \%$ of other managers find managers trade unions necessary.

\section{CONCLUSION}

The hypothesis $\mathrm{H} 1$ is confirmed and it led to the result that the character traits of leaders in the textile industry in Serbia are very important for their selection. The auxiliary hypothesis is also confirmed; the greater the impact of character traits of leaders, the greater the importance of certain roles of managers, and thus is increased the efficiency of employees. The following is the interpretation of the research results using the factor analysis. Based on the survey, the age structure of the Serbian textile companies leaders is that among them elderly people prevail. The average age of leaders is 46.3 years, while the mode or most frequent age of 46 years.

Based on the educational structure of the leaders it can be seen why certain variables are together, and why they behave in the same way spatially. For example, the variables - University degree behave in the same way, and are mostly described by the first factor (Factor 1), so that,on the basis of these variables, it is named the first variable - Factor 1. Variables - Economist, Lawyer, Engineer and Organizer behave in the same way, and are mostly characterized by the second factor (Factor 2), so that, on the basis of these variables, it is named the second variable - Factor 2. Variables - The structure of leaders according to their social background (rural, worker-class, clerical and intellectual) behave the same way and are mostly characterized by the third factor (Factor 3), so that, on the basis of these variables, it is named the third variable - Factor 3. Variables- The position of leaders in society and their internal and external activities, operational and strategic activities, behave in the same way and are mostly characterized by the fourth factor (Factor 4), so that, on the basis of these variables, it is named the fourth variable - Factor 4. Variables - The importance of specific measures of success of the managers have their segments that behave in the same way and are mostly characterized by the fifth factor (Factor 5), so that, on the basis of these variables, it is named the fifth variable - Factor 5.Variables - The attitudes of leaders on the importance of the certain roles of managers have their segments that behave in the same way and are mostly characterized by the sixth factor (Factor 6), so based on these variables, it is named the sixth variable - Factor 6.Variables - Determining the differences between leaders and other managers behave in the same way and are mostly characterized by the seventh factor (Factor 7), so based on these variables it is named the seventh variable - Factor 7. Variables - Determining the differences between leaders and other managers in ranking the importance of certain stakeholders to be met, behave in the same way and are mostly characterized by factor eight (Factor 8), so based on these variables, it is named the eight variable Factor 8.

By grouping variables an attempt was made to create more independent factors (separated groups of new factors F1, F2, F3, F4, F5, F6, F7, F8). Separated factors are the result of discriminant analysis that is basically a discriminant function on which the assumed variables are well-designed. This study of leaders and managers' character traits can serve for the purpose of their selection as well as of improving the efficiency of the production process in Serbia. 


\section{REFERENCES}

Bass, B. M., \& Stogdill, R. M. (1990). Bass \& Stogdill's handbook of leadership: Theory, research, and managerial applications. New York: Free Press.

Bennis, W., \& Nanus, B. (1985). Leaders: The strategies for taking change. New York: Harper \& Row.

Cialdini, R. B. (1988). Influence: Science and practice. Clenview, IL: Scott, Foresman.

Elkington, R., \& Breen, J. M. (2015). How Senior Leaders Develop Resilience in Adversity: A Qualitative Study. Journal of Leadership, Accountability and Ethics, 12(4), 93-110.

Feist, J., \& Feist, G. (2009). Theories of Personality (7 ed.). New York: McGraw-Hill.

Geier, J. G. (1967). A trait approach to the study of leadership in small groups. Journal of Communication, 17(4), 316-323. doi: 10.1111/j.1460-2466.1967.tb01189.x

Greenberg, J., \& Baron, R. (1995). Behavior in Organizations Understanding and Managing the Human Side Of Work. New Jersey: Prentice Hall.

House, R. J., \& Aditya, R. N. (1997). The social scientific study of leadership: Quo vadis? Journal of Management, 23(3), 409-473. doi: $10.1177 / 014920639702300306$

Judge, T. A., Bono, J. E., Ilies, R., \& Gerhardt, M. W. (2002). Personality and leadership: a qualitative and quantitative review. Journal of Applied Psychology, 87(4), 765-780.

Kaul, V. (2011, 30.09.2011). The necktie syndrome: Why CEOs tend to be significantly taller than the average male. The Economic Times.
Kiarie, M. A. W., Maru, L. C., \& Cheruiyot, T. K. (2017). Leader personality traits and employee job satisfaction in the media sector, Kenya. The TQM Journal, 29(1), 133-146. doi: 10.1108/TQM-092015-0117

Kirkpatick, S. A., \& Locke, E. A. (1991). Leadership: do traits matter? Academy of Management Perspectives, 5(2), 48-60. doi: 10.5465/ame.1991.4274679

Kotter, J. (1990). A force for change: How management differs from leadership. New York: FreePress.

Krech, D., Crutchfield, R., \& Livson, N. (1958). Elements of psychology. San Francisco: University of California, Berkeley.

Lord, R. G., De Vader, C. L., \& Alliger, G. M. (1986). A meta-analysis of the relation between personality traits and leadership perceptions: An application of validity generalization procedures. Journal of Applied Psychology, 71(3), 402-410.

Oludele Mayowa, S., Idowu, E., \& Ekundayo, J. (2016). Exploring the relationship between leadership communication style, personality trait and organizational productivity. Serbian Journal of Management, 11(1), 99-117. doi: 10.5937/sjm118480

Yukl, G. A. (1959). Leadership in organization. Englewood, New Jersey: Prentice-Hall.

Zaccaro, S. J., Foti, R. J., \& Kenny, D. A. (1991). Selfmonitoring and trait-based variance in leadership: An investigation of leader flexibility across multiple group situations. Journal of Applied Psychology, 76(2), 308-315.

\title{
ODREĐIVANJE OSOBINA LIČNOSTI I KARAKTERA LIDERA, NJIHOVA SELEKCIJA I EFIKASNOST U TEKSTILNOJ INDUSTRIJI
}

\begin{abstract}
Sa aspekta specifičnosti ličnosti u menadžmentu ukazano je da će organizacije bolje funkcionisati ukoliko osobe na liderskim pozicijama imaju određene osobine ličnosti. Praktičan, ali suštinski zadatak lidera je stvaranje novih pristupa i pronalaženje novih oblasti za istraživanje . Hipoteza koja je u osnovi ovog rada , prikazuje da osobine ličnosti imaju veliki uticaj na povećanje efikasnosti lidera u tekstilnoj industriji u Srbiji. U radu su dati rezultati za starosnu strukturu, profesionalnu strukturu, socijalno poreklo lidera, poziciju u društvu, uspeh rada menadžera, važnost nekih uloga menadžera. Znanje i veštine se stiču i razvijaju kroz teoriju i praktično iskustvo, dok su neke specifične veštine početna karakteristika koju pojedinac ima ili nema. Ova profesija zahteva od osobe da poseduje određene osobine ličnosti kako bi bila uspešna i kako bi se uspešno obavili zadaci.
\end{abstract}

Ključne reči: Osobine ličnosti, Selekcija, Efikasnost, Lider, Proizvodnja. 